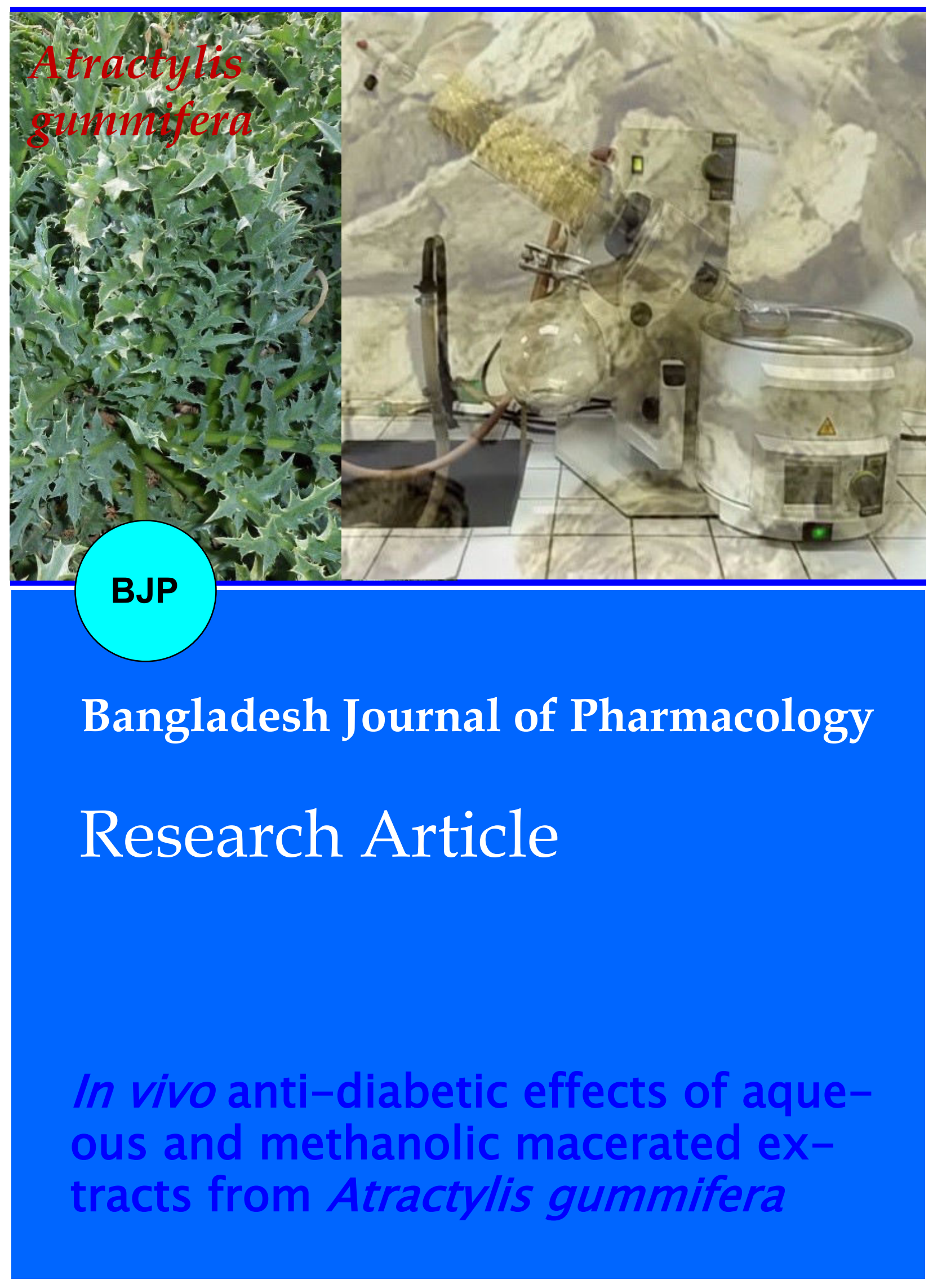




\title{
In vivo anti-diabetic effect of aqueous and methanolic macerated extracts of Atractylis gummifera
}

\author{
Khadija Bouabidi, 2, Fatima Lamchouri', Hamid Toufik', Mohamed Boulfia', Souad \\ Senhaji ${ }^{1}$ and My El Abbes Faouzi ${ }^{2}$
}

${ }^{1}$ Laboratory of Materials, Natural Substances, Environment and Modeling, Polydisciplinary Faculty of Taza, Sidi Mohamed Ben Abdellah University of Fez B. P., 1223 Taza-Gare, Taza, Morocco; ${ }^{2}$ Laboratory of Pharmacology and Toxicology, Pharmacokinetics Research Team, Faculty of Medicine and Pharmacy, Mohammed V University, BP 6203, Rabat-Institutes, Rabat, Morocco.

\begin{tabular}{|c|c|}
\hline \multicolumn{2}{|l|}{ Article Info } \\
\hline Received: & 17 November 201 \\
\hline Accepted: & 1 March 201 \\
\hline Available Online: & 14 April 201 \\
\hline \multicolumn{2}{|c|}{ DOI: 10.3329/bjp.v14i2.38870 } \\
\hline \multicolumn{2}{|c|}{ Cite this article: } \\
\hline \multicolumn{2}{|c|}{ Bouabid K, Lamchouri F, Toufik H, } \\
\hline \multicolumn{2}{|c|}{$\begin{array}{l}\text { Boulfia M, Senhaji S, Faouzi MEA. In } \\
\text { vivo anti-diabetic effect of aqueous }\end{array}$} \\
\hline \multirow{2}{*}{\multicolumn{2}{|c|}{$\begin{array}{l}\text { and methanolic macerated extracts } \\
\text { of Atractylis gummifera. Bangladesh J }\end{array}$}} \\
\hline & \\
\hline & 4: 67-73. \\
\hline
\end{tabular}

\begin{abstract}
The anti-diabetic effect of Atractylis gummifera (plant used in traditional Moroccan medicine) has been evaluated in type 2 diabetic mice model. The mice were divided into five groups: Normal control, diabetic control, diabetic treated with aqueous macerate $(500 \mathrm{mg} / \mathrm{kg})$, diabetic treated with methanol macerate $(500 \mathrm{mg} / \mathrm{kg})$ and diabetic treated with metformin $(300 \mathrm{mg} / \mathrm{kg})$. The treatment of the mice was performed by daily gastric gavage for 5 weeks. The monitoring of the mice was carried out weekly by fasting glucose and measurement of biochemical parameters at the end of treatment. The aqueous macerate of A. gummifera was most effective that reduced the fasting blood glucose with $62.7 \%$. In addition, this extract restored the biochemical parameters of diabetic mice to normal.
\end{abstract}

\section{Introduction}

Diabetes is a chronic disease characterized by insulin deficiency or resistance (OMS, 1999). The treatment of diabetes depends on its typology. Type 1 diabetes is treated with insulin therapy, as for type 2 diabetes, which in addition to diet and lifestyle changes, is treated with oral anti-diabetic agents that have a beneficial effect on lowering blood glucose levels, but they also have many adverse effects and contraindication that affect the quality of life of the diabetic patient (Group et al., 1986).

Several plants such as Allium cepa (Campos et al., 2003), Gaultheria trichophylla (Alam and Saqib, 2017), Nigella sativa (Meddah et al., 2009), Olea europaea (Long et al., 2010), Origanum vulgare (Lemhadri et al., 2004), Salvia officinalis (Eidi and Eidi, 2009), Trigonella foenum-graecum (Hamza et al., 2012), Verbena officinalis (Sheyla et al., 2011) have been reported to have anti-diabetic effect. Moroccans also use medicinal plants to treat type 2 diabetes (Bellakhdar et al., 1991). The results of these surveys have revealed a very long list of medicinal plants used in the treatment of type 2 diabetes. To confirm or refute this use, we have opted for a plant which is widely used in traditional Moroccan medicine for the treatment of several diseases such as epilepsy, psoriasis, ulcers and hemorrhage (Hammich et al., 2013; Bnouham et al., 2006). It is named Atractylis gummifera L., and in Moroccan dialect it is called Added or Chouk el Elk.

A. gummifera is considered a toxic plant, but its toxicity depends on the dose, the part of the plant ingested and how it is prepared (Vallejo et al., 2009). However, studies have shown that this plant has a beneficial effect in free radical scavenging and prevention against oxidative stress (Khadhri et al., 2015) which is a triggering factor for several metabolic diseases including diabetes (Asgharpour et al., 2013).

To verify the anti-diabetic properties of A. gummifera, 
we tested in vitro the hypoglycemic effect of eight aqueous and organic extracts of this plant by inhibiting a-amylase, a-glucosidase and $\beta$-galactosidase, the enzymes responsible for the digestion of polysaccharides and therefore for increasing blood glucose levels. Thus, we have selected two extracts that have proved to be the most active and which are aqueous and methanolic macerates (Bouabid et al., 2018). This in vitro activity has bio-guided us in this study, the objective is to evaluate in vivo the hypoglycemic effect of A. gummifera in diabetic mice.

\section{Materials and Methods}

\section{Chemicals used}

Streptozotocin, nicotinamide and methanol were purchased from the Sigma-Aldrich (USA).

\section{Plant material}

The harvest of A. gummifera was carried out in the Commune of Tahla, Province of Taza, which is located in the region of Fez-Meknes, Morocco. The botanical identification of the species of A. gummifera was made using the available flora (Quezel and Santa, 1990; Tela Botanica, 2012; Valdés et al., 2002) by Prof. Abdeslam Ennabili and Dr. Abdelmajid Khabbach. A herbarium sheet under the code SE01 was made and deposited in the Laboratory of Materials, Natural Substances, Environment and Modelling of the Polydisciplinary Faculty of Taza, Sidi Mohamed Ben Abdellah University of Fez.

\section{Preparation of extracts}

Two extracts were prepared by maceration and based on the results of the in vitro study (Bouabid et al., 2018). The aqueous/methanol macerate was prepared by dissolving the plant material composed of the underground part of the A. gummifera in cold water/methanol for 24 hours.

\section{Animals used}

The male Swiss Albino mice (weight: 25-35 g) were used and obtained from the animal house of the Faculty of Medicine and Pharmacy, Mohammed V University of Rabat-Morocco. All animals were housed in collective cages at room temperature $\left(25^{\circ} \mathrm{C}\right)$ and lit on a cycle of 12 hours of light over 12 hours of dark with access to water and food.

\section{Acute toxicity}

Two groups of mice $(n=6)$ selected by random sampling were used for the study of acute toxicity of aqueous or methanol macerate extract by gastric gavage in a single dose $(2,000 \mathrm{mg} / \mathrm{kg})$ after being fasted overnight, providing only water. Then, the mice were monitored during the first $30 \mathrm{~min}$ after force-feeding, first 24 hours and daily for 14 days.

\section{Diabetes induction}

The induction of diabetes was made by intraperitoneal injection of freshly prepared solution of streptozotocin $(200 \mathrm{mg} / \mathrm{kg})$, followed by an injection of nicotinamide (210 mg/kg) (Junod, 1967). The induction of diabetes was checked one week later by blood glucose measurement using the On call plus meter 01554. In case of mouse with a fasting glucose level greater than $126 \mathrm{mg} / \mathrm{dL}$, the measurements were done twice before inclusion as diabetic model (Junod, 1967).

\section{Treatment}

Thirty mice were divided into five groups: a) Nondiabetic; b) untreated diabetic; c) diabetic treated with aqueous macerate of $A$. gummifera; d) diabetic treated with methanol macerate of A. gummifera; e) diabetic treated with metformin $(300 \mathrm{mg} / \mathrm{kg})$.

The diabetic mice were treated with either aqueous or methanol macerate of A. gummifera at a dose of $500 \mathrm{mg} /$ $\mathrm{kg}$ corresponding to a quarter of the dose tested in the acute toxicity study of $2,000 \mathrm{mg} / \mathrm{kg}$.

\section{Follow-up}

During the entire treatment period of 5 weeks, the followings were assessed: a) Daily: By measuring the body weight, b) Weekly: By measuring the fasting blood glucose. The blood was taken during fasting from the tail of the mouse before gastric gavage to determine the blood glucose level. The results were expressed in terms of milligrams per deciliter of blood.

The percentage decrease in blood glucose is calculated by the following equation:

$\%$ Decrease in blood glucose $=[($ final blood glucose initial blood glucose) / initial blood glucose] $\times 100$

At the end of treatment, the blood sample was drawn from the mice for the assay of several biochemical parameters.

In addition to the measurement of the fasting blood glucose once a week during the entire period of study, the determination of the glucose level was also carried out in the serum of different groups of mice at the end of treatment (Trinder, 1969).

\section{Biochemical parameters}

The established methods were used for the determination of creatinine (Fabiny and Ertingshausen, 1971), total proteins (Watanabe, 1986), free and esterified cholesterol (Allain et al., 1974), and triglycerides (Bucolo and David, 1973).

The determination of aspartate aminotransferase was based on the catalysis transfer of the amine group of aspartate to 2-oxoglutarate by ASAT, forming oxaloacetate and glutamate (Approved recommendations, 
1985a). The determination of alanine aminotransferase was based on the transfer of the amino group from alanine to 2-oxoglutarate by ALAT, forming pyruvate and glutamate according to the method which was based on measuring the quantifiable staining intensity by spectrophotometer at $340 \mathrm{~nm}$ (Approved recommendations, 1985b).

\section{Statistical analysis}

Results were expressed as mean of six mice from each group \pm standard error mean (SEM). Data of body weight and fasting blood glucose of different groups of mice during the treatment period were analyzed by two -way analysis of variance (two-way ANOVA) Bonferroni post-test. As for biochemical parameters they were analyzed by one-way analysis of variance (one-way ANOVA) Tukey posttest using the software GraphPad Prism. Differences were considered significant at $\mathrm{p}<0.05$.

\section{Results \\ Extraction yield}

The extraction yields for aqueous macerate and methanol macerate were 24.5 and $6.7 \%$ respectively.

\section{Acute toxicity}

No death was observed for mouse after being given aqueous and methanolic macerates of A. gummifera at a dose of 2,000 mg/kg. Similarly, mice showed no signs of toxicity such as behavioral changes, tremors, seizures, salivations, diarrhea, sleep, or coma. This means that the extracts were safe at $2,000 \mathrm{mg} / \mathrm{kg}$.

\section{Body weight}

A gain in body weight was observed in the diabetic mice treated with either metformin, aqueous macerated or macerated methanol with statistically insignificant differences between these groups (data not shown). However, a decrease in weight was observed in the untreated diabetic group which had an average weight at baseline of $27.1 \pm 1.3 \mathrm{~g}$ and became $24.2 \pm 1.0 \mathrm{~g}$ with statistically significant difference between the beginning and the end of treatment period.

\section{Fasting blood glucose level}

The results of the weekly blood glucose measurement during the 5 weeks show a normal glucose level in nondiabetic mice averaging $101 \pm 1.0 \mathrm{mg} / \mathrm{dL}$ (Figure 1). The administration of streptozotocin to mice resulted in the destruction of $\beta$-cells of the islets of Langerhans responsible for the secretion of insulin, which explains high glucose level in the blood of untreated diabetic mice $387.5 \pm 43.6 \mathrm{mg} / \mathrm{dL}$. During the treatment of diabetic mice, a significant decrease in the level of blood glucose was found in the first week of treatment of diabetic mice compared to untreated diabetic mice, whether the treatment was by aqueous and methanolic macerates of A. gummifera or by the reference medicine, metformin. This decrease in glucose level was better in diabetic mice treated with aqueous macerate $(-62.7 \%)$, followed by diabetic mice treated with metformin $(-59.4 \%)$, and in the third place, the mice treated with methanolic macerate $(-37.1 \%)$ with statistically significant differences between the three groups.

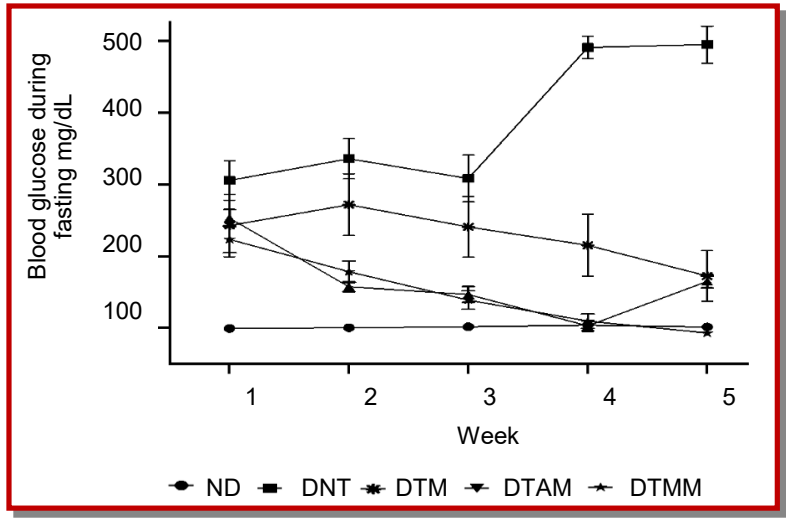

Figure 1: Change in blood glucose during fasting of different groups of mice during the treatment period (Mean $\pm S E M) n=$ 6, ND: No Diabetics; UD: Untreated diabetics; DTM: Diabetics treated with metformin; DTAM: Diabetics treated by aqueous macerated; DTMM: Diabetics treated with macerated methanol

\section{Biochemical parameters}

The aspartate and alanine transaminase levels for nondiabetic mice were $137.2 \pm 11.6$ and $40.7 \pm 2.5 \mathrm{IU} / \mathrm{L}$, respectively. However, untreated diabetic mice showed a significant increase in these enzymes by compared to non-diabetic mice with respective aspartate and alanine transaminase values of $389.6 \pm 58.1$ and $315 \pm 49.0 \mathrm{IU} / \mathrm{L}$. Similarly, the level of these enzymes increased with statistically significant differences in the diabetic mice treated with metformin compared to non-diabetic mice with respective aspartate and alanine transaminase values of $283.2 \pm 22.4$ and $50.7 \pm 3.3 \mathrm{IU} / \mathrm{L}$. In addition, mice treated with $A$. gummifera macerates showed an increase in aspartate and alanine transaminase levels with a statistically significant difference compared to normal mice with respective values of aspartate and alanine transaminase of $484.2 \pm 8$ and $142.2 \pm 2 \mathrm{IU} / \mathrm{L}$ for the aqueous macerate and $506.5 \pm 89$ and $342.8 \pm 96 \mathrm{IU} /$ $\mathrm{L}$ for the macerated methanol. However, the increase in the level of these enzymes was much greater in the macerated methanol than the aqueous macerate. The aqueous macerate is less hepatotoxic than methanolic macerate (Figure 2).

\section{Urea and creatinine levels}

The mean urea and creatinine values in non-diabetic mice were $0.3 \pm 0.0$ and $3.8 \pm 0.2 \mathrm{mg} / \mathrm{L}$, respectively. They increased significantly in untreated diabetic mice with urea and creatinine values of $0.3 \pm 0.0$ and $4.7 \pm 0.2$ $\mathrm{mg} / \mathrm{L}$. This increase in serum creatinine and urea 


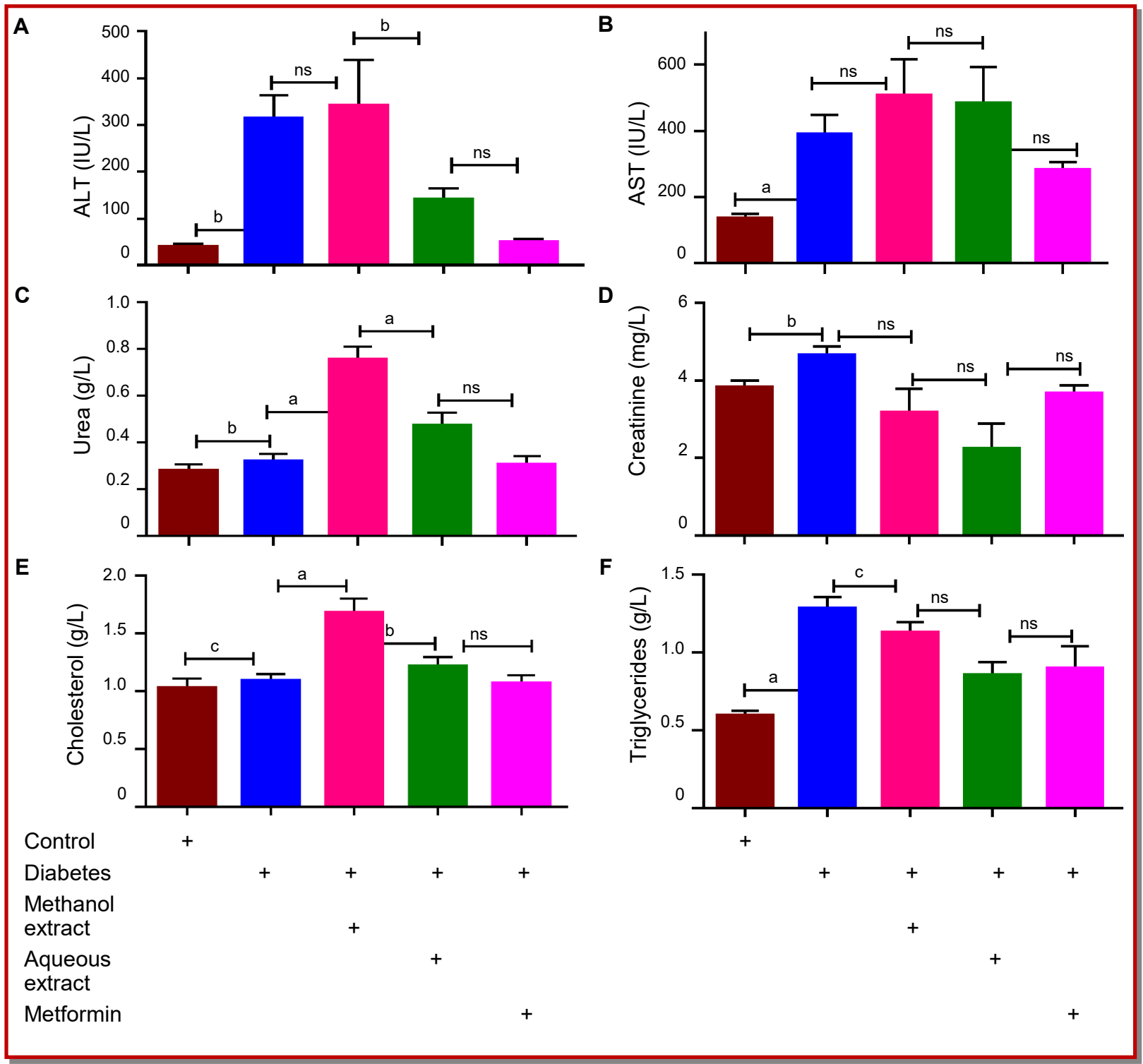

Figure 2: Variation in alanine transaminase (ALT)(A), aspartate transaminase (AST)(B), urea (C), creatinine (D), cholesterol (E) and triglycerides $(\mathrm{F})$ levels in the blood of different groups of mice

ns: Difference not statistically significant; Statistically very significant differences a $<<0.001$; Difference moderately statistically significant ${ }^{b} \mathrm{p}<0.01$; Statistically significant differences ${ }^{c} \mathrm{p}<0.05(\mathrm{n}=6)$

concentration in diabetic mice dropped significantly in diabetic mice treated with macerates of A. gummifera and metformin. Indeed, the creatinine level became 2.3 $\pm 0.6 \mathrm{mg} / \mathrm{L}$ after treatment of diabetic mice by aqueous macerate, and $3.2 \pm 0.6 \mathrm{mg} / \mathrm{L}$ after treatment with macerated methanol, and $3.7 \pm 0.2 \mathrm{mg} / \mathrm{L}$ after treatment with metformin with differences statistically insignificant between these last three groups and significant compared to the tested mice, non-diabetic mice and untreated diabetic mice (Figure 2).

\section{Cholesterol and triglycerides}

The cholesterol and triglyceride levels in non-diabetic mice were $1.0 \pm 0.2$ and $0.6 \pm 0.0 \mathrm{~g} / \mathrm{L}$ respectively. While hypercholesterolemia and hypertriglyceridemia were observed in untreated diabetic mice with a statistically significant difference compared to non-diabetic mice with respective values of $1.3 \pm 0.1$ and $1.3 \pm 0.1 \mathrm{~g} / \mathrm{L}$ (Figure 2). The administration of the aqueous macerate of A. gummifera decreased cholesterolemia and serum triglyceride levels in diabetic mice with statistically significant differences compared to untreated diabetic mice and non-diabetic mice in the range of $1.2 \pm 0.1$ and $0.9 \pm 0.1 \mathrm{~g} / \mathrm{L}$. Similarly, metformin decreased the lipid profile in diabetic mice with respective cholesterol and triglyceride values of $1.1 \pm 0.1$ and $0.9 \pm 01 \mathrm{~g} / \mathrm{L}$ and with statistically significant differences compared to untreated diabetic mice and non-diabetic mice, and non 
-significant differences compared to mice treated with aqueous macerate.

\section{Total proteins}

The total protein level in non-diabetic tested mice was $62.3 \pm 3.4 \mathrm{~g} / \mathrm{L}$, but decreased with a significant difference in untreated diabetic mice to $57.2 \pm 2.7 \mathrm{~g} / \mathrm{L}$. This explains the weight loss of these mice. However, treatment of diabetic mice with A. gummifera macerates increased serum total protein levels with respective values for aqueous macerate and methanol macerate of $63.3 \pm 2.8$ and $78.8 . \pm 2.5 \mathrm{~g} / \mathrm{L}$ with a statistically significant difference between these two extracts, and also compared to untreated diabetic mice and nondiabetic mice (data not shown).

\section{Discussion}

In the present study, the extracts of A. gummifera (macerated aqueous and methanolic) possess in vivo an anti-diabetic activity which makes it possible to correct the glycaemia and to prevent the complications of diabetes mellitus.

In the literature in vivo, no study on the anti-diabetic activity of A. gummifera has been performed previously, but our results are in agreement with other studies conducted on Moroccan and international plants that have shown that plant extracts can reduce blood glucose and renal and hepatic dysfunction in diabetic mice such as N. sativa (Benhaddou et al., 2011; Labhal et al., 1999), and E. angustifolia fruited of China (Wang et al., 2018). Moreover, the therapeutic dose that we have used $(500 \mathrm{mg} / \mathrm{kg}$ ) is much lower than the toxic dose and is similar to the most commonly dose of plant used for the treatment of diabetes mellitus as garlic alcoholic extract $(500 \mathrm{mg} / \mathrm{kg}$ ) which has reduced blood sugar to 57\% (Eidi et al., 2006; Thomson et al., 2007).

Furthermore, our study differs from others works by the effectiveness of aqueous extract cold prepared (macerated), which will make it easier to prepare the oral anti-diabetic based on A. gummifera and will minimize the secondary effects. The extraction with solvents is used for isolation of different compounds, and yield of the extracts have a strong relationship with the solvent employed, mainly due to the different polarity of compounds obtained (Moure et al., 2001). For this reason, two solvents were assayed in this work (water and methanol) and the yield of the aqueous extract was much better than methanol macerate which is attributed to the polarity of water which is greater than the polarity of methanol, and the molecules that A. gummifera contains have a greater affinity for water than methanol. Many similar works have shown that when the polarity of the solvent decreased the extraction yield decreased in the same order (A.
Fernández-Agulló et al., 2013; Al-Farsi and Lee, 2008).

In this study, diabetic mice showed a significant increase in blood sugar levels compared to normal mice. This can be due to streptozotocin which damages the pancreatic islet $\beta$-cells, and prevents the normal secretion of insulin, thus causing an increase in blood glucose levels. Also, results showed that aqueous macerated of A. gummifera can significantly $(\mathrm{p}<0.05)$ reduce blood glucose in diabetic mice, which it's presumably due to reducing the damage of streptozotocin to pancreatic $\beta$-cells and enhancing the secretion of insulin (Wang et al., 2018). Also this decrease in blood sugar can be attributed to the richness of this extract in phenolic compounds (polyphenols and flavonoids) and in tannins (Bouabid et al., 2018) which are known for their ability to increase insulin sensitivity by the users' organs (liver, adipose tissue, muscle) and/ or inhibit the polysaccharide degradation process (Swanston-Flat et al., 1990; Asgharpour et al., 2013).

In addition, a weight loss in untreated diabetic mice which is a clinical sign of discontinuation in the storage of glucose in the form of glycoprotein and glycolipids. It is a sign of the release of the process of glycogenolysis, lipolysis and proteolysis which will be triggered for obtaining ATP. The latter will subsequently cause weight loss in the untreated diabetic mice (Martin et al., 2017). However, type 2 diabetes is characterized not only by an imbalance in glucose homeostasis, but especially by a micro and macro angiopathic complications, hence the need to analyze the biochemical parameters like aspartate and alanine transaminase which are the enzymes that were released after the destruction of the cells of the liver. So, the higher level of these enzymes was the risk of developing liver failure, which is noted in all our treated or untreated diabetic mice. However, the aqueous macerate is less hepatotoxic than methanolic macerate which allows us to deduce that the use of an organic solvent is more hepatotoxic than the aqueous extract. This increase can be attributed to the hepatotoxic effect of streptozotocin used for the induction of diabetes; which is already reported in the literature (Palsamy et al., 2008). In addition, the increase in these enzymes may be an indication of hepatic necrosis developed in diabetic mice (Larcan et al., 1979).

We also dosed creatinine and urea which are considered as specific markers of renal dysfunction (Almadal and Vilstrup, 1988), cholesterol and triglyceride which are responsible for micro and macro angiopathic complications (Taylor et al., 2013), we found that $A$. gummifera aqueous macerate is the best extract that can prevent micro and macro angiopathic complications in diabetic subjects as well as methanol macerated which was able to restore total protein level to normal. Therefore, the aqueous macerate of A. gummifera may well be a promising source of an oral anti-diabetic that 
would restore the level of glucose in the blood to normal, prevent the complications of diabetes and reduce insulin resistance. Besides, this extract has a very important role in inhibiting the enzymes responsible for the degradation of polysaccharides that has been demonstrated in vitro (Bouabid et al., 2018). Indeed, phytochemical screening revealed that the aqueous macerate of $A$. gummifera is an extract that contains tannins and flavonoids (Bouabid et al., 2018). Hence, molecular synergy has a beneficial effect in this case, which explains the action of this extract on several biochemical parameters and the restoration of their values back to normal.

\section{Conclusion}

The extracts of A. gummifera (macerated aqueous and methanolic) possess in vivo a significant anti-diabetic activity.

\section{Acknowledgements}

The authors are thankful to the Botanists Dr. Abdelmajid Khabbach and Prof. Abdeslam Ennabili for their help in identification of the species. Also, thanks are addressed to Dr. Meryem Bouabid and Dr. Kamal Zereouale for their help in performing biochemical analyzes and their interpretation.

\section{Ethical Issue}

The acute toxicity study was conducted according to the method described in OECD Guideline 425 of the Organization for Economic Co-operation and Development.

The ethics approval was obtained from Mohammed V University in Rabat under the responsibility of the Central Animal and Laboratory of Pharmacology and Toxicology of the Faculty of Medicine and Pharmacy of Rabat. The study was conducted in accordance with the principles outlined in the Guide for the Care and Use of Laboratory Animals prepared by the National Academy of Sciences. Every effort has been made to minimize animal suffering and the number of animals used.

\section{Conflict of Interest}

The authors declare that there is no conflict of interests regarding the publication of this paper.

\section{References}

Alam F, Saqib Q. Anti-diabetic potential of Gaultheria trichophylla in mice. Bangladesh J Pharmacol. 2017; 12: 29298.

Al-Farsi M, Lee CY. Optimization of phenolics and dietary fibre extraction from date seeds. Food Chem. 2008; 108: 977-
85.

Allain CC, Poon LS, Chan CS, Richmond W. Enzymatic determination of total serum cholesterol. Clin Chem. 1974; 20: 470-75.

Almadal TP, Vilstrup H. Strict insulin treatment normalizes the organic nitrogen contents and the capacity of urea-N synthesis in experimental diabetes in rats. Diabetologica 1988; 31: 114-18.

Approved recommendations. On IFCC Methods for the measurement of catalytic concentration of enzymes. Part 2: IFCC method for aspartate aminotransferase, 1985a.

Approved recommendations. On IFCC Methods for the measurement of catalytic concentration of enzymes. Part 3: IFCC method for alanine aminotransferase. 1985b.

Asgharpour F, Pouramir M, Khalilpour A, Alamdari SA, Rezaei M. Anti-oxidant activity and glucose diffusion relationship of traditional medicinal antihyperglycemic plant extracts. Int J Mol Cell Med. 2013; 2: 169-76.

Bellakhdar J, Claisse R, Fleurentin J, Younos C. Repertory of standard herbal drugs in the Moroccan Pharmacopoea. J Ethnopharmacol. 1991; 35: 123-43.

Benhaddou AA, Martineau L, Vuong T, Meddah B, Madiraju P, Settaf A, Haddad PS. The in vivo anti-diabetic activity of Nigella sativa is mediated through activation of the AMPK pathway and increased muscle Glut 4 content. Evid Based Complement Altern Med. 20 11; 2011.

Bnouham M, Merhfour F, Elachoui M, Legssyer A, Mekhfi H, Lamnaouer D, Ziyyat A. Toxic effects of some medicinal plants used in Moroccan traditional medicine. Moroccan J Biol. 2006; 3: 21-30.

Bouabid K, Lamchouri F, Toufik H, Sayah K, Cherrah Y, Faouzi MA. Phytochemical screening and in vitro evaluation of alpha amylase, alpha glucosidase and beta galactosidase inhibition by aqueous and organic Atractylis gummifera $L$. extracts. Plant Sci Today. 2018; 5: 103-12.

Bucolo G, David H. Quantitative determination of serum triglycerides by use of enzymes. Clin Chem. 1973; 19: 476-82.

Campos KE, Diniz YS, Cataneo AC, Faine LA, Alves MJ, Novelli EL. Hypoglycaemic and antioxidant effects of onion, Allium cepa: Dietary onion addition, antioxidant activity and hypoglycaemic effects on diabetic rats. Int J Food Sci Nutr. 2003; 54: 241-46.

Eidi A, Eidi M. Anti-diabetic effects of sage (Salvia officinalis L.) leaves in normal and streptozotocin-induced diabetic rats. Diabetes Metab Syndr. 2009; 3: 40-44.

Eidi A, Eidi M, Esmaeili E. Anti-diabetic effect of garlic (Allium sativum L.) in normal and streptozotocin-induced diabetic rats. Phytomedicine 2006; 13: 624-29.

Fabiny DL, Ertingshausen G. Automated reaction-rate method for determination of serum creatinine with centrichem. Clin Chem. 1971; 17: 696-700.

Fernández-Agullóa A, Pereira Eb, Freirea MS, Valentãoc P, Andradec P, González-Álvarez J, Pereira JA. Influence of solvent on the antioxidant and antimicrobial properties of walnut (Juglans regia L.) green husk extracts. Ind Crops Prod. 2013; 42: 126-32. 
Groop LC, Pelkonen R, Koskimies S, Bottazzo GF, Doniach D. Secondary failure to treatment with oral anti-diabetic agents in non-insulin-dependent diabetes. Am Diabet Assoc. 1986; 9: 129-33.

Hammich V, Merad R, Azzouz M. Plantes toxiques à usage médicinal du pourtour méditerranéen. Paris, SpringerVerlag, 2013.

Hamza N, Berke B, Cheze C, Le Garrec R, Umar A, Agli AN, Lassalle R, Jové J, Gin H, Moore N. Preventive and curative effect of Trigonella foenum-graecum L. seeds in C57BL/6J models of type 2 diabetes induced by high-fat diet. J Ethnopharmacol. 2012; 142: 516-22.

Junod A. Studies of the diabetogenic action of streptozotocin. Proc Soc Exp Biol Med. 1967; 126: 201.

Khadhri A, El mokni R, Smiti S. Composés phénoliques et activités antioxydantes de deux extraits de chardon à glu: Atractylis gummifera. Revie Soc Sci Nat. 2015; 39: 44-52.

Labhal A, Settaf A, Zalagh F, Cherrah Y, Hassar M, Slaoui A. Propriétés anti-diabétiques des graines de Nigella sativa chez le Merione shawi obèse et diabétique. Espérance médicale. 1999; 6: 72-74.

Larcan A, Lambert H, Laprevote-Heully MC, Delorme N. Light and electronmicroscopic study of hepatic lesions in the course of hyperlactatemia indiabetic patients. Diab Metab. 1979; 5: 103-12.

Lemhadri A, Zeggwagh NA, Maghrani M, Jouad H, Eddouks M. Anti-hyperglycaemic activity of the aqueous extract of Origanum vulgare growing wild in Tafilalet region. J Ethnopharmacol. 2004; 92: 251-56.

Long H.S, Tilney P.M, Van Wyk B. The ethnobotany and pharmacognosy of Olea europaea subsp. africana (Oleaceae). S Afr J Bot. 2010; 76: 324-31.

Martin C, Vallet V, Riou B. Physiologie humaine appliqué. 2e éd. John Libbey Eurotext Amazon France, 2017.

Meddah B, Ducroc R, Faouzi ME, Eto B, Mahraoui L, Benhaddou-Andaloussi A, Martineau LC, Cherrah Y, Haddad PS. Nigella sativa inhibits intestinal glucose absorption and improves glucose tolerance in rats. J Ethnopharmacol. 2009; 121: 419-24.

Moure A, Cruz JM, Franco D, Dominguez H, Sineiro J, Dominguez H, Núnez MJ, Parajó JC. Natural antioxidants from residual sources. Food Chem. 2001; 72: 145-71.

Organisation mondiale de la Santé. Definition, diagnosis and classification of diabetes mellitus and its complications. Part 1, WHO/NCD/NCS/99.2. Genève, 1999.
Palsamy P, Subramanian S. Resveratrol, a natural phytoalexin normalizes hyperglycemia in streptozotocin-nicotinamide induced experimental diabetic rats. Biomed Pharmacother. 2008; 62: 598-605

Quezel P, Santa S. Nouvelle flore de l'Algérie et des régions désertiques méridionales, Editions CNRS, Paris; 1962-63. Swanston-Flat SK, Day C, Bailey CJ, Flatt PR. Traditional plant treatment for diabetes: Studies in normal and streptozotocin diabetic mice. Diabetologia 1990; 33: 462-64.

Sheyla R, Olman H, Mikel G, Iñigo N, Iciar A, Diana A, Cavero Y, Calvo I. Chemical composition, mineral content and antioxidant activity of Verbena officinalis L. Food Sci Technol. 2011; 44: 875-82.

Swanston-Flat SK, Day C, Bailey CJ, Flatt PR. Traditional plant treatment for diabetes: Studies in normal and streptozotocin diabetic mice. Diabetologia 1990; 33: 462-64.

Taylor F, Huffman MD, Macedo AF, Moore THM, Burke M, Davey Smith G, Ward K, Ebrahim S. Statins for the primary prevention of cardiovascular disease. Cochrane Database Syst Rev. 2013; CD004816.

Tela Botanica. Le réseau des Botanistes Francophones. http:// www.tela botanica.org/site:botanique, 2012.

Thomson M, Al-Amin Z, Al-Qattan K, Shaban L, and Ali M. Anti-diabetic and hypolipidaemic properties of garlic (Allium sativum) in streptozotocin-induced diabetic rats. Int J Diabetes Metab. 2007; 15: 108-15.

Trinder P. Determination of glucose in blood using glucose oxidase with an alternative oxygen acceptor. Ann Clin Biochem. 1969; 6: 24-27.

Valdés B, Rejdali M, El Kadmiri A, Jury J, Montserrat M. Catalogue des plantes vasculaires du Nord du Maroc incluant des clés d'identification. Editions CSIC, Madrid; 2002.

Vallejo JR, Peral D, Gemio P, Carrasco M, Heinrich C. Atractylis gummifera and Centaurea ornata in the Province of Badajoz (Extremadura, Spain): Ethnopharmacological importance and toxicological risk. J Ethnopharmacol. 2009; 126: $366-70$.

Wang Y, Hong M, Cui S, Tao G, Zai PF. Hypoglycemic potential of Elaeagnus angustifolia fruit polysaccharide on streptozotocin-induced type 2 diabetic mice. Bangladesh J Pharmacol. 2018; 13: 297-301.

Watanabe N. Urinary protein as measured with a pyrogallol red-molybdate complex, manually and in a Hitachi 726 automated analyzer. Clin Chem. 1986; 32: 1544-51. 